\title{
Borders inscribed on the body: geopolitics and the everyday in the work of Martín Kohan
}

Article

Accepted Version

Mcallister, C. (2020) Borders inscribed on the body: geopolitics and the everyday in the work of Martín Kohan. Bulletin of Latin American Research, 39 (4). pp. 453-465. ISSN 1470-9856 doi: https://doi.org/10.1111/blar.13089 Available at https://centaur.reading.ac.uk/89299/

It is advisable to refer to the publisher's version if you intend to cite from the work. See Guidance on citing.

Published version at: http://dx.doi.org/10.1111/blar.13089

To link to this article DOI: http://dx.doi.org/10.1111/blar.13089

Publisher: Wiley-Blackwell

All outputs in CentAUR are protected by Intellectual Property Rights law, including copyright law. Copyright and IPR is retained by the creators or other copyright holders. Terms and conditions for use of this material are defined in the End User Agreement.

www.reading.ac.uk/centaur

\section{CentAUR}


Central Archive at the University of Reading

Reading's research outputs online 


\title{
Borders inscribed on the body: geopolitics and the everyday in the work of Martín Kohan
}

\author{
Dr Catriona McAllister, University of Reading
}

\begin{abstract}
This article analyses the critique of militaristic geopolitical worldviews in two novels by Martín Kohan (Dos veces junio, 2002 and Ciencias morales, 2007). Drawing on 'everyday nationalism' and the insights of feminist geopolitics, it explores these novels' use of space and gendered violence to present Argentina's 1976-83 dictatorship and the Falklands/Malvinas war as unexceptional manifestations of the relationship between the state and its citizens. This reading foregrounds Kohan's emphasis on the origins and consequences of national identity discourses, framed as powerful narratives capable of generating a vision of the nation-state that privileges the security of borders over bodies.
\end{abstract}

\section{Keywords}

Feminist geopolitics; Argentina; Martín Kohan; military; everyday nationalism

Martín Kohan's literary work spans a wide range of themes, from sport to the figure of San Martín, but a questioning of ideas of Argentine nationhood and national narratives is rarely far beneath the surface. This article analyses two of Kohan's best-known works, Dos veces junio (2002) and Ciencias morales (2007), as contestations of traditional geopolitical perspectives within Argentine identity discourses. If traditional geopolitics places the integrity and security of the national territory at the heart of defining the nation-state, then 
Kohan's narratives can be seen as unravelling the wide-ranging consequences of privileging territory (and its protection) within the discursive production of the nation.

This focus offers a valuable framework for reading Kohan's critique of Argentina's 1976-83 military dictatorship and the Falklands/Malvinas conflict (within which both novels are set). It allows the novels' questioning of the deeper roots of these events, rather than just their immediate political circumstances, to shine through. Importantly, neither text can be easily categorised as either a novel of the dictatorship or a Malvinas novel: they deliberately integrate the international conflict and the domestic military regime in order to highlight the political inseparability of the two phenomena. These novels therefore occupy an interesting space within the broader landscape of memory discourses and literary responses to the war and the dictatorship. They eschew the tradition of anti-epic, parodic representations of the Malvinas conflict (Vitullo, 2012), instead dismantling the war by presenting it within a broader framework of violence. They are written substantially later than the allegorical responses to dictatorship analysed by Avelar (1999), and are therefore framed by a different stage of the memory debate: the 'boom of memory' of the mid-1990s/early 2000s and the (early moments of) the centring of human rights within political discourse under kirchnerismo (Ros, 2012). Yet they very clearly offer us a fictional rather than testimonial or autofictional pact, positioning themselves not as an attempt to recover experience, but as examinations of deep structural underpinnings of this period of history. These novels can therefore be read both within and against the wider memory context, as part of a broadening conversation about the dictatorship and its legacy (Blejmar, 2016) - particularly in the case of Ciencias morales - while also consciously rejecting some of the most prevalent aesthetic approaches to the period.

By avoiding aesthetic conventions such as testimony and parody, the novels occupy a more open literary space that allows them to constantly draw our attention away from the 
specific context of the dictatorship and war, and instead to hone in on long-standing national identity discourses that both foreground the primordiality of territory and celebrate the historical delimitation of this through military means. Reading the texts through different conceptions of geopolitics therefore provides an intersection between the novels' presentation of several key themes, including warfare (as a defense of national borders), the role of the military in national life (as the guarantors of territorial security) and historical discourses that present military shaping of national borders as coterminous with the creation of the nationstate. This focus therefore underscores the links between the texts' historically-rooted perspective and their insistence on the lived, embodied consequences of narrative constructions of the nation-state.

The significance of the relationship between these thematic strands of the novels can be clearly seen by reading them alongside Kohan's writings as a prominent literary and cultural critic, particularlyhis discussions of the place of war in Argentina's national imaginary. Kohan has explicitly addressed the commemoration of the national military past and the predominance of territorial understandings of the nation-state, particularly in his book-length essay El país de la guerra (2014), in which he argues that war has been hardwired into Argentina's self-conception since the early post-independence decades. For Kohan, Argentina's traditional origin narrative asserts that the patria was forged through military might and the protection of national borders, a vision that combines glory and the defeat of enemies. This broader perspective highlights the importance of understanding the novels' critique as extending beyondthe Falklands/Malvinas conflict and the Argentine military's self-construction as the 'saviours' of the patria, underscoring instead a much more deeply-rooted narrative construction of the nation-state that privileges the defence of national borders above all else. 
The vision of 'traditional geopolitics' that I will argue is deconstructed in Kohan's two novels is therefore one that unites territory, the military and the definition of the nationstate. The positioning of territorial integrity as a core component of the nation-state is both a familiar geopolitical discourse and one that has enjoyed a prominent position in Argentina: Escolar, Quintero Palacios \& Reboratti (1993) go as far as to describe the nationalistic idea of a 'patriotic territory' as one that has become 'part of the common sense of Argentines' (362). This implies a sense of inviolable national borders, all the more relevant here due to the direct influence of geopolitical thinking on the shaping of the geography taught in schools throughout the twentieth century (Romero, 2004: 86), and the rapid growth of the study of geopolitics in military settings during the Cold War in Argentina, Chile and Brazil, leading Romero (2004: 86) to argue that 'es inevitable vincular el desarrollo del campo geopolítico con los proyetos de legitimación de los últimos regímenes militares' (it is inevitable to link the development of the field of geopolitics to the legitimising projects of the most recent military regimes). The idea that the Argentine nation-state is defined through its territorial composition runs through each of these elements, linking traditional geopolitics, patriotism and the political narratives of Argentina's late twentieth-century military regime, and it is this complex discursive landscape that implicitly underpins the critique mounted by Kohan's fiction. It is not warfare in an abstract sense that comes under fire in these novels, therefore, but the easy slippage between patriotism and the military protection of territorial integrity, which precludes other possible understandings of the security that a state can offer its citizens.

Kohan's narrative perspective on the link between recent Argentine history and patriotic identity discourses can therefore be more clearly unravelled by reading the novels as reflections on how and where these particular geopolitical discourses operate. The novels expose the myriad ways in which geopolitical understandings are unthinkingly woven into 
everyday life, highlighted by the texts' displacement of major historical events from centrestage in favour of a more intimate narrative. This slippage draws our attention to the role of the everyday, and this article will explore the ways in which Kohan uses the local and the intimate to challenge dominant geopolitical narratives and their position in public life. My analysis will therefore use insights from feminist geopolitics and other understandings of the role of the everyday (particularly articulations of the concept of 'everyday nationalism') to explore the ways in which Kohan's novels present the most traumatic events of Argentina's recent past not as exceptional events, but rather as a consequence of violence and militaristic thinking in the broader discursive and political system.

\section{Nationalism, geopolitics and the everyday}

As highlighted above, the relationship between the nation-state's borders and forms of nationalistic thinking in Argentina is crucial to Kohan's critique. Forms of nationalism are peppered throughout the twonovels and can usefully be analysed through the concept of 'everyday nationalism'. This term (as developed by Jones and Merriman, 2009) expands and contests Michael Billig's concept of 'banal nationalism'. While banal nationalism notes the routine, unremarked flagging of the nation in everyday public life, seen as key preparation for 'hot' (overt) nationalism and conflicts, everyday nationalism identifies constant shifts and movements between banal forms of nationalism and overt expressions linked to geopolitical hostilities. It therefore highlights fluid connections between different expressions of nationalism that transcend 'the banal-blatant binary' (Benwell, 2014) or the complex interweaving of 'hot' and 'banal' nationalism (Jones and Merriman, 2009; Christian, Dowler and Cuomo, 2016; Benwell and Dodds, 2011). The concept of 'everyday nationalism' therefore enables a more nuanced understanding of the presence of more overt forms of nationalistic thinking in everyday situations, particularly in settings more traditionally associated with 'banal' practices, such as schools (Benwell, 2014). This conceptualisation of 
the everyday emphasises the deliberate nature of some 'flagging' of the nation, rather than just unconscious routines. It reminds us that familiar reminders of nationhood are not necessarily subtle, and provides a vocabulary for conscious interventions in the geopolitical landscape by a range of actors. Identifying the interweaving of different and deliberate forms of nationalism in the two novels studied here is important to understanding their narrative strategies.

My framing of the everyday will also draw substantially on the contributions of feminist geopolitics, which asserts the importance of interactions between different sites of geopolitical discourse and action. This is often positioned as a question of scale, stressing the need for more granular explorations of the geopolitical. Dowler and Sharp (2001: 174) explain how focusing on different scales foregrounds 'the complex relations between the international and everyday [...] ensuring that small, mundane daily practices of everyday life are understood in relation to the reconstructions of the nation and the international'. The 'everyday' here encompasses domestic settings, not merely the daily encounters with markers of the nation in public life. It therefore challenges the separation between public and domestic space and seeks to reassert the agency of more localised practices: the ways in which individuals perform and make meaning of geopolitical concepts.

This question of scale in feminist geopolitics is particularly used as a means of understanding interactions between different sites of power. Massaro and Williams (2013), for example, argue that feminist geopolitics "demonstrates how the "apolitical", "feminine" private realm is a key component in the operation of global power' (570) and that the theoretical constructs of feminist geopolitics '[provide] tools that enable us to see the way in which power operates in similar ways across such disparate sites and scales' (567). Dixon and Marston (2011: 446) seek to explore 'how space and power are differentially experienced and embodied', whilst Hyndman (2001: 212) highlights that 'global processes, whether 
economic, political, or socio-cultural, are experienced in localized, everyday, embodied ways'. The embodied nature of geopolitical experiences (and action) is crucial in these final two conceptualisations, with Hyndman identifying 'the safety of the body as the finest scale of geopolitical space' (2001: 216). This question of scale extends beyond the local or the domestic, therefore, positing the body as another key site for the enactment of geopolitical practices.

Departing from this understanding of scale, Hyndman (2001) argues for the need to redefine ideas of 'security', shifting from state security to that of individuals and groups. This not only asserts the embodied nature of security, but also encompasses security on home soil rather than just protection from international threats. Significantly, this conception enables recognition of specific groups within the nation-state rather than a homogenous idea of the citizenry, with Massaro and Williams (2013: 573) arguing that 'feminist geopolitics deconstructs the notion of state-provided security to recognise its uneven distribution across nationality, gender, race, and sexuality'. It also opens the possibility of considering types of violence not usually understood as 'geopolitical' through this lens, as a failure of the state to fulfil its duty of guaranteeing security to its citizens. Whilst sexual violence in conflict situations is often recognised as a weapon of war, this broader understanding includes sexual violence within the nation. Discussing the US, but with clear relevance to other contexts, Christian, Dowler \& Cuomo (2016: 65) highlight that this is type of violence is often portrayed as apolitical, rather than 'exposing how the nation is shaped in relation to sexual violence and fear'. By interpreting the geopolitical imperative to provide security as applicable at the level of the individual body, feminist geopolitics opens new spaces of accountability, enabling gaps in national discourse to be highlighted and new connections across different discursive sites to be drawn. 
Feminist geopolitics will therefore inform my understanding of the 'everyday' in Kohan's work in two key ways. I will explore how spaces not usually understood as geopolitical, particularly domestic and other intimate settings, are deployed in relation to discourses of nationhood and security in the texts. My analysis will also foreground the embodied dimension of geopolitics: the gendered inscription of security discourses and nationalism onto the bodies of both men and women in the two novels, and embodied enactments of geopolitical power at a local level.

This approach provides a framework for analysing the ways in which these novels interrogate and dismantle a particular conception of the relationship between individuals and the state. While the texts can be seen to enact what Diana Taylor (1997: 16) terms 'the construction of [Argentine] national identity as predicated on female destruction', the frameworks of feminist geopolitics help to show how they also go beyond this, conducting a forensic interrogation of a form of patriotism that guarantees borders over bodies. Julieta Vitullo (2012: 102) notes the importance of bodies as a site of critique in Ciencias morales, but the framework used here helps to pinpoint the specific ways in which gendered bodies are used against broader discourses of national construction and ideas of security. The novels of course offer a critique of authoritarianism (Skrepetz, 2013), achieved in large part through the careful unravelling of the ideological force of both discourse and silence (Valcheff García, 2017), but they also plunge us deep into an exploration of the roots of this discourse and outline its daily consequences not just under dictatorship or on the battlefield, but in the everyday lived experience of citizens. In this way, my analysis will explore the layering of geopolitical discourses in the texts and the critiques that are generated by bringing together different understandings of the relationship between security, violence, gender and the nation. 


\section{Ciencias morales: Intimate geopolitical dramas and the violence of the}

\section{everyday}

Ciencias morales is primarily set in the famous Colegio Nacional de Buenos Aires against the backdrop of the Falklands/Malvinas conflict. The novel won the Premio Herralde, a prestigious prize for new novels in Spanish, and was made into a film as La mirada invisible in 2010. We follow the experiences of María Teresa, a young woman working as a preceptora at the school, whose professional role centres on maintaining rigid standards of discipline. The action follows the minutiae of María Teresa's existence, from her daily routines at school to the home life she shares with her mother, which is marked by the absence of her brother due to national military service. Throughout the novel, the military conflict remains largely 'off-stage', with school and domestic life occupying the foreground. It is therefore the everyday that is the heart of the text, with dramatic events (whether personal or international in scale) framed through daily routines and mundane details. In this way, the novel refuses to position the Falklands/Malvinas conflict (and its deep connection to the military regime) as something 'other' or exceptional. Instead, the war becomes a naturalseeming part of the broader geopolitical and educational landscape, seamlessly integrated with the militaristic, patriarchal codes seen at work across every sphere of experience presented by the text.

Explicit interventions by the state are almost absent in the novel, but its workings are clearly encoded into public and private spaces, particularly the school. I have previously analysed the novel's representation of practices that can be described as 'banal nationalism', from the unremarked presence of flags and busts of military heroes, through to school rituals seen as a natural 'rite of passage' for young citizens (McAllister, forthcoming). However, the novel's constant switching between the public, overtly masculinised space of the school and 
the domestic setting of the home (inhabited exclusively by female characters) is also crucially important. Both the hot and banal are present in these spaces: planes fly overhead to the conflict, while news bulletins in the background of everyday life recount the latest information from the front line. 'Hot' expressions of nationalism therefore insert themselves into daily life as mere background noise rather than as a notable rupture of the existing order; there is no noticeable shift from one to the other. Nor is there any respite from the consequences of the state's geopolitical workings in domestic or intimate space, as shall be seen below.

The school is marked as a masculine space, an educational institution conceived and created for boys only. While the Colegio now accepts female students, it is clear that they have simply been inserted into the existing masculine, military patriotic structures. This is underscored at several moments in the text, such as when the presence of female voices in one of the school's key patriotic rituals is perceived as 'disonante' (dissonant) (Kohan, 2007: 205), or when the act of a female pupil merely putting up her hand to speak is considered shocking by the preceptora (124). While the text relentlessly critiques this militarised, patriarchal structure, we cannot look to the female protagonist herself as a source of rebellious inspiration. María Teresa is a disquieting figure for several reasons, not least her acritical acceptance of her own role within the repressive system. Despite the fact we are privy to her intimate thoughts (as much of the novel is told from her perspective), she demonstrates little understanding of the wider structures she serves and no critical capacity to question the discipline she so willingly enforces. She ascribes no agency to herself, merely implementing what is asked. In this way, she is another symbol of the complicit Argentine citizenry seen in several other texts representing this period (Plotnik, 2016). Significantly, the text does not deny the protagonist's agency in these actions; there is no exoneration of 
individuals overwhelmed by a faceless 'system', but rather an observation of her failure to challenge inherited behavioural and discursive codes.

While the 'hot' military conflict is largely represented through fleeting glimpses and allusion, the presence of militaristic, geopolitical thinking is a constant, pervading all aspects of the school's day-to-day education. When María Teresa covers for an absent history teacher, pupils are asked to comment on dictated quotations on the subject of war. Still more significantly, an art lesson focuses on nineteenth-century artist Cándido López’s paintings of the Paraguayan War: a school subject that could be used to discuss aesthetics or analyse abstract concepts is transformed into a lesson on Argentina's military exploits and its place in the world. This scene switches between María Teresa's own thoughts and narrative passages on Cándido López and the war, seemingly capturing fragments of the lesson itself. The narration demonstrates the discursive sleight of hand that wrests a celebratory narrative from a fraught historical event, reminding us that 'la Guerra del Paraguay, si bien se mira, se terminó ganando' (When you think about it, the Paraguayan War was won in the end) (Kohan, 2007: 120). The intimate connections between the school's own history, Argentina's military past and the narration of nationally significant events are underscored in this scene through mentions of Bartolomé Mitre, who, the narrator reminds us, not only founded the school and launched Argentina's participation in this war, but also founded a hugely influential national newspaper (La Nación) and provided the first history of the country's two most important national heroes. Through these seamless connections, the military defence of the nation-state's borders becomes indissociable from the narration of national history and children's education, a blurring that echoes Kohan's argument in El país de la guerra, in which the figure of Mitre looms large. This scene therefore depicts border-defining warfare as an everyday part of the school's education, underscoring the centrality of this discourse in educating young Argentines about their national belonging. These everyday interactions 
therefore pointedly take the place of overt descriptions of the conflict, tracing narratives with a traditional geopolitical perspective as an unquestioned part of the landscape of national identity discourses.

Intrusions of discourses that deal with recognisably geopolitical themes are therefore an important strand of the text, but the core of the narrative is driven by a personal, intimate drama that becomes another site for the enactment of the same constructions. We follow the protagonist's evolving obsession as she becomes fixated with a pupil, Baragli, convincing herself that this is part of her rigorous performance of her duties rather than an untoward attraction. After suspecting the boy of smoking, she devises a plan to catch the perpetrators in the act by spying in the boys' bathroom. This turns into a daily practice that becomes the preceptora's sole enjoyment and pleasure, her initial aim quickly forgotten as she loses herself in a morbid fascination with the sounds and smells of the boys' lavatory. The boys' bathroom is, of course, a symbolically charged space within the context of the Colegio. It embodies the gendered norms and power structures of the school (as recognised also by Vitullo, 2012), presenting a clear-cut binary divide that brooks no ambiguity or transgression. It is also the most intimate, private space on the school grounds, a place exempt from the public ritual and routine that governs the school's outward-facing life, built to accommodate the private needs of the individual body. The fact that the novel's central dramatic tension revolves around this intimate, gendered and bodily space underscores the centrality of these spheres to the framing of its political critique.

While the protagonist tries to rationalise her behaviour as supportive of the school's mission, her presence in this exclusively male, private space, and her unwitting sexual arousal (which she labels innocently as a 'cosquilleo', a tickle or tingling), are transgressions that take her outside the sanctioned structures. As María Teresa sinks further into the pleasure of the universe she has created for herself, living for the moments she spends in her 
unconventional hide-out, a dramatic unravelling of this alternative reality seems inevitable. Beneath the measured, steady tone of the narrative, excruciating tension builds as we wait to learn how and when she will be discovered.

The moment of her discovery represents a violent intrusion of the patriarchal, geopolitical logic of the school into this intimate space. The jefe de preceptores (María Teresa's boss), Señor Biasutto, eventually invades the intimate space she has carved out for herself and discovers her hiding in a cubicle. This moment plays out in heart-stopping slow motion as Biasutto methodically searches the bathroom in a scene caught between the terrible suspense of a horror film and the grammar of war. Biasutto's violent forcing of the cubicle door places María Teresa under siege, as one 'golpe brutal' (brutal blow) is followed by another, while she awaits her fate in terrified silence, described as 'su última trinchera y su última esperanza' (her last trench and her last hope) (Kohan, 2007: 176). The language of warfare is therefore explicitly evoked in the description of the scene, allowing geopolitical logic to invade the most private, intimate space on the school premises.

Yet this violent discovery is only the beginning of the aggression María Teresa will face. Biasutto encourages María Teresa to recommence her surveillance, offering her hope that her acts will be understood as a contribution to the school's discipline rather than a transgression. However, when she next takes up her hiding place, Biasutto sexually assaults her in a clearly premediated, calculated act. This act of sexual violence is described in excruciating detail, marking an abrupt shift from the allusive, understated narrative tone that dominates most of the novel. The painstaking description of María Teresa's thoughts during the assault, blending her fear with observations of the most mundane details surrounding her, echoes the layering of forms of nationalism described above: aggression is once more set against a backdrop of the everyday. Significantly, the assault is not an isolated event, but is repeated, followed by the chilling words 'el lunes la quiero acá, ¿sabe?’ (On Monday I want 
you here, ok?) (211) which seal her fate, seeing her condemned to suffer this repeated violence with no apparent possibility of escape.

Biasutto is the character most closely associated with the military regime throughout the novel, deploying and defending the logic of the proceso. As a result, this assault can be read as an act of state violence: an act legitimised by the discursive and political landscape within which it positions itself. This is not an act of personal evil, but the logical consequence of the structures of state power sustained by the institutional environment. María Teresa is also quickly turned from a complicit spy, helping to facilitate this logic, to one of its victims. Or perhaps even more disturbingly, she inhabits both spaces at the same time. Even those who facilitate and support the dominant discourse are shown to be disposable, easily expelled from the covenant of security. The contract the protagonist believes she holds with the state and its related power structures is shattered. Instead, her blind loyalty to the system is rewarded with brutal physical violation that replicates the power dynamics she has been helping to reproduce.

One of the most devastating aspects of this depiction of violence is the protagonist's continued preoccupation with her ability to conform to the patriarchal constructs of sexual behaviour to which she continues to aspire. She has internalised the patriarchal insistence on female purity so deeply that she clings to the fact that the assault she has experienced has not taken her virginity (as the perpetrator has had to use his fingers rather than his penis to achieve penetration), and that she is therefore still technically 'una señorita'. She comforts herself with the thought that she can still conform to the rules and expectations of patriarchal society, and she perceives no alternative to the discursive codes that surround her even when their inability to offer her personal security has been so brutally revealed. It is significant that her transgression is not intended as a rebellious act: she is not seeking to disrupt the nationstate's status quo, but still she finds herself without protection. 
If, in the words of Hyndman (2004: 318), bodies 'become public sites of violence on which constructions of the nation and its boundaries take place', then María Teresa's experience of violence becomes emblematic of the consequences of accepting geopolitical discourses of security that defend the territory of the nation-state rather than the bodily integrity of citizens. The interweaving of the background presence of Malvinas helps us to understand this act of sexual violence as an expression of the climate of nationalistic discourses that circulate throughout the text, and ultimately as an act of war itself. As Christian, Dowler \& Cuomo (2016: 67) highlight, 'systemic rape is most often associated with "hot" conflicts', but here the sexual assault takes place within an institutional setting on home soil, transforming a mundane and intimate space into a site where the nation can potentially wage war on its own citizens. The protection of citizens therefore reveals itself to be a dispensable responsibility, secondary to the defence of borders and territory. The potential of intimate, everyday spaces to become sites of geopolitical violence is also emphatically underscored, and the unequal access to security present in traditional geopolitical logic is drawn to the fore.

María Teresa's embodied experience of violence self-consciously replaces any traditional physical depiction of warfare in the text, with the Malvinas conflict largely represented through fleeting, oblique references. The embodied nature of warfare is still evoked, however, through the figure of her brother: a conscript travelling south whose cryptic, oblique postcards and brief phone calls avoid any explicit description of his military experiences. He is an absent male body whose suffering is unspoken, but the intrusion of his communications into the domestic space of the home draw our attention constantly back to the military conflict, reasserting its significance for every scene in the text. Despite the brother's assumed direct role in this geopolitical dispute, it is the female body that visibly suffers the violent effects of war, while the brother himself is decorporealised. This shifts our 
focus from the transnational (male) space of war to this personal experience of geopolitical violence, again returning us to a broader definition of geopolitical discourses that incorporates every scale of lived experience.

Ultimately, it is the end of the 'hot' geopolitical conflict, the end of military action in the Falklands/Malvinas, that saves both María Teresa and her brother from the threat of ongoing violence. Following Argentina's defeat, the school is closed for several days, and once it reopens Biasutto and other key figures have been replaced, freeing the protagonist from the clutches of her abuser. At the same time, this event frees her brother from his own physical ordeal at the hands of the junta (and in the name of a geopolitical cause): fighting on the front line. As the protagonists retire from their direct contributions to geopolitical enforcement (María Teresa on the home front of school discipline and her brother on the battlefield), they transition into a new normality, the consequences of which remain unstated. Although both characters are restored to a sense of bodily security by the end of the text, there is no guarantee that this will endure: we sense that this is, at best, a quiet reprieve, and that the rules of the game remain ultimately unchanged.

\section{Dos veces junio: Gendered Violence and the Figure of the Soldier}

Dos veces junio can be read as a sister novel to Ciencias morales in many ways, focusing as it does on the period of the dictatorship. Most of the novel is set in 1978, framing the experience of a young man undertaking national military service against the backdrop of Argentina hosting the world cup (and particularly against the national team's loss to Italy in a group game, despite ultimately going on to win the tournament). The 'second June' referred to in the novel's title is that of 1982 , with this section centring on the aftermath of the Malvinas conflict. The novel's fragmented structure moves rapidly between different narrative strands and relies on jarring juxtapositions to generate much of its critique of the 
hypermasculine, militarised and abusively violent universe it depicts. As in Ciencias morales, embodied consequences of state security discourses are again centre stage. Gendered experiences of state-inflicted violence and warfare punctuate the narrative and are brought into self-conscious dialogue with other everyday experiences of nationalism, creating a layered critique of warfare and its accompanying geopolitical logic.

Unlike Ciencias morales, this earlier novel includes direct representation of crimes against humanity explicitly committed by the 1976-83 military regime. It depicts one of the most widely denounced human rights abuses of the dictatorship: the kidnapping of babies from female prisoners. Female experiences of violence are inflicted - directly and indirectly by the military-controlled state, and once again acts of gendered violence are not presented as individual acts but as a consequence of the wider system of violence and control.

This is particularly evident in the potent current of sexual violence against women that runs through the novel, from the public to the private sphere. Significantly, it is not the sexual violence against female prisoners as an act of state terrorism that occupies the foreground, but rather an omnipresent threat of sexual violence across multiple sites and not explicitly targeted at an 'enemy'. In one section (titled Cinco), the action shifts between descriptions of a violent scene from a porn film and the protagonist recalling one of his own sexual experiences with a prostitute. The film depicts a group of soldiers gang-raping a girl, while the protagonist's own encounter focuses on how violence and control fuelled his own pleasure. The protagonist's account of his experience is also reimagined as a dream at the end of the novel, in which a significant linguistic slippage creeps in: the first time we hear the account, he remembers his partner to have said 'me estás matando' (you're killing me) (Kohan, 2013: 108), but later this is altered to 'matame soldadito' (kill me, soldier) (188), a switch to the imperative that implies a consent and enjoyment potentially absent in the original sexual encounter. As in Ciencias morales, characters' experiences are removed from 
the realm of the personal and displaced into the geopolitical, here through the insistence on the military position of the protagonist and of the perpetrators of the sexual violence in the pornographic film scene. Security for individual bodies, particularly women's bodies, is replaced with military positions being used to render women vulnerable, unsafe or in a position of exploitation. The novel depicts this form of violence as 'hard-wired' into the concept of war and therefore as inherently bound up with the concept of the nation, again returning us to this finest scale of bodily security as a key focus.

The novel also draws overt and direct parallels between different gendered roles of self-sacrifice in the name of the nation. In a discussion about pregnant guerrilleras, a key character, Doctor Mesiano, presents pregnancy as a form of military cowardice, an unsoldierly female attempt to exploit maternal fertility in order to gain protection (116-7). He contrasts this with what he sees as a legitimate use of the female body to further the nation's geopolitical goals, describing prostitutes in Vietnam who deliberately spread syphilis among the enemy. Mesiano therefore presents women as able to sacrifice their bodies through illness and sex, offering a warped translation of male (soldier) honour codes onto the female body. His argument centres on ownership of the body, portraying each individual's physical form as belonging to the nation in the same way that, he argues, a prostitute ceases to own her own body: 'en una guerra, los cuerpos ya tampoco son de nadie: son pura entrega, son puro darse a una bandera y una causa' (in a war, bodies no longer belong to anyone: they are just given over, surrendered to a flag and a cause) (120). This insistence on the physical incarnation of sacrifice in the name of the national places the body at the centre of the individual's relationship to the nation-state. Rather than a provision of security, geopolitical discourse offers an expectation of sacrifice and a collective understanding of physicality that ultimately undermines the very idea of the individual. 
This insistence on a conception of the geopolitical that seamlessly blends the violent, the military and the everyday returns insistently throughout the novel. Doctor Mesiano reveals his ability to recite Argentine historical figures famous for their action 'en la política o en la guerra, si es que cabía hacer tal distinción' (in politics or in war, if such a distinction could be drawn) (81), emphasising the inseparability of these dimensions of the state (and not just during the proceso, but throughout the nation's history). The figure of the flag is also used to draw comparisons between multi-layered forms of identification with the nation, from the national football team to Malvinas and annual celebrations of national heroes. Football supporters wave flags at the protagonist on duty in his military uniform, illustrating the easy association between the two due to this national symbol (58), while flags are later described as hanging from balconies with a range of potential readings and symbolism, from the world cup to Malvinas or in honour of Manuel Belgrano, celebrated as the flag's creator (170). It is the ambiguity of this second instance that is particularly significant, with all of these different forms of national public life collapsed easily into a seemingly innocuous symbol. The text therefore insists on the presence of these 'banal' forms of nationalism, but explicitly links them not only to 'hot' conflicts but also to gendered violence within the nation itself, charting a landscape that relies upon celebrations of military heroism to enable everyday encounters that create very unequal access to bodily security.

The novel's conclusion, set in the aftermath of the Malvinas conflict, offers little in the way of redemption. It is in these final pages of the novel that male bodies suffer the consequences of the geopolitical stakes: the narrator discovers that Mesiano's son has been killed in combat, one name among a list of other young men lost to the conflict. We also see the displacement of bodies and the breaking of biological bonds, overridden by the power structures of state violence, as the child born to a female prisoner is now being raised within Mesiano's family. The sense that lessons may not be learned weighs heavy on this final 
scene, as a radio journalist insists on the need for Argentines to be 'más unidos que nunca' (more united than ever) (187), a pronouncement that seems to call for a continuation rather than an overhaul of citizens' relationship to the nation-state. The effect of embodied forms of state violence and their connection to a traditional geopolitical understanding of the nation is therefore not only consistently condemned throughout the text, but also portrayed as a status quo that is unacknowledged and therefore stands to remain unchanged.

\section{Conclusion: Borders Inscribed on the Body}

Both Ciencias morales and Dos veces junio foreground lived, embodied experiences of violence perpetrated by individuals representing state 'security'. The violence is also gendered, with women consistently experiencing insecurity in their daily lives, whilst male bodies only come under threat in 'hot' military conflicts. It takes place in intimate settings, with the most obviously geopolitical bodily insecurity (warfare) appearing in glimpses rather than direct depictions. In this way, the texts emphasise the insidious influence of geopolitical logic and the unequal security it provides in everyday encounters, creating an indissociable connection between these examples of brutality and the gentle insistence on being members of the nation that accompanies events in both texts.

Reading these novels through the framework of feminist geopolitics therefore places violence against women at the heart of their critique of traditional geopolitical worldviews (and the close relationship between these discourses and forms of identification with the nation in the novels). The texts continually link the inscription of state violence on the female body to war, ideas of the nation and everyday experiences of nationalism. Moreover, they emphasise often ignored sites of geopolitical practice, highlighting 'the lived realities of individuals and communities' rather than 'global scale and placeless state power' (Massaro and Williams, 2013: 569). They also imply that every individual contributes to geopolitical 
meaning-making, whether through obvious roles such as belonging to the military or seemingly tangential roles such as enforcing discipline in a school. In this way, both novels force our attention towards the granular scale at which state discourses of security operate, and insistently return to the question posed by Hyndman (2004): security for whom? This focus places the novels' questioning into sharp relief, highlighting an urgent need to rewrite these rules, removing their militaristic overtones and perhaps even rethinking the notion of patriotism altogether.

The most significant impact of the focus on the embodied and the everyday in both texts is the emphasis upon the lack of exceptionality of acts of state violence against citizens, particularly in terms of the ways in which militaristic thinking is depicted as embedded in this day-to-day context. Replacing the depiction of warfare between nation-states with local, individualised narratives of gendered violence does not dismiss the importance of institutional and national context, but instead illustrates the ways in which everyday geopolitical meaning-making takes place around and upon individual bodies. As a result, the military regime and the Falklands/Malvinas conflict stand not as isolated events within the texts, but instead as part of a broader logic that operates at all levels of society. If these patterns are never to be repeated, the novels suggest, then the patriotic contract between the nation-state and its citizens must be made anew, creating guarantees of security for bodies alongside, or perhaps even instead of, borders.

\section{Reference list}


Avelar, I. (1999) The Untimely Present: Postdictatorial Latin American Fiction and the Task of Mourning. Duke University Press: Durham, N.C.

Benwell, M.C. (2014) 'From the Banal to the Blatant: Expressions of Nationalism in Secondary Schools in Argentina and the Falkland Islands'. Geoforum 52: 51-60.

Benwell, M.C., Dodds, K. (2011) ‘Argentine Territorial Nationalism Revisited: The Malvinas/Falklands Dispute and Geographies of Everyday Nationalism'. Political Geography 30: 441-449.

Blejmar, J. (2016) Playful Memories: The Autofictional Turn in Post-Dictatorship Argentina. Palgrave Macmillan: Cham, Switzerland.

Christian, J., Dowler, L. and Cuomo, D. (2016) 'Fear, Feminist Geopolitics and the Hot and Banal'. Political Geography, Special Issue: Banal Nationalism 20 years on 54: 6472.

Dixon, D.P. and Marston, S.A. (2011) 'Introduction: Feminist Engagements with Geopolitics'. Gender, Place \& Culture 18: 445-453.

Dowler, L. and Sharp, J. (2001) 'A Feminist Geopolitics?' Space and Polity 5: 165-176.

Escolar, M., Quintero Palacios, S. and Reboratti, C. (1993) 'Geography, Identity and Patriotism in Argentina' in D. Hooson (ed.) Geography and National Identity. Blackwell: Oxford, 346-366.

Hyndman, J. (2001) 'Towards a Feminist Geopolitics'. The Canadian Geographer / Le Géographe canadien 45: 210-222.

Hyndman, J. (2004) Mind the Gap: Bridging Feminist and Political Geography through Geopolitics. Political Geography 23: 307-322.

Jones, R. and Merriman, P. (2009) 'Hot, Banal and Everyday Nationalism: Bilingual Road Signs in Wales'. Political Geography 28: 164-173. 
Kohan, M., (2007) Ciencias morales. Anagrama: Barcelona.

Kohan, M. (2013) Dos veces junio. Debolsillo: Buenos Aires.

Kohan, M. (2014) El país de la guerra. Eterna Cadencia: Buenos Aires.

Massaro, V.A. and Williams, J. (2013) ‘Feminist Geopolitics'. Geography Compass 7: 567577.

McAllister, C. (forthcoming) 'Flying the Flag: Malvinas and Questions of Patriotism' in Guillermo Mira Delli-Zotti (ed.) Revisiting the Falklands/Malvinas Question: Transnational and Interdisciplinary Perspectives. ILAS: London.

Plotnik, V. (2016) 'Dictadura militar y sociedad civil. Clase media y responsabilidad colectiva en novelas argentinas de las últimas dos décadas'. Perífrasis 7: 25-38.

Romero, L. A. (2004) La Argentina en la escuela: la idea de nación en los textos escolares. Buenos Aires: Siglo XXI.

Ros, A. (2012) The post-dictatorship generation in Argentina, Chile, and Uruguay: collective memory and cultural production. Palgrave Macmillan: New York.

Skrepetz, I. (2013) 'María Teresa: uma imagem mórbida da nação argentina em Ciencias morales de Martín Kohan'. Millenium, 45: 123-140

Taylor, D. (1997) Disappearing Acts: Spectacles of Gender and Nationalism in Argentina's “Dirty War.” Duke University Press: Durham, N.C. ; London.

Valcheff García, F. N. (2017) 'Una herida abierta. Tensiones y contrapuntos discursivos en Dos veces junio y Ciencias morales, de Martín Kohan'. Catedral tomada, 5(8): 66-83

Vitullo, J. (2012) Islas imaginadas: la guerra de Malvinas en la literatura y el cine argentinos. Corregidor: Buenos Aires. 